\title{
Application of the Poka Yoke Method in the Mix Packing Part Process to Control the Amount of Flow Out
}

\section{Penerapan Metode Poka Yoke Pada Proses Mix Packing Part untuk Mengendalikan Jumlah Flow Out}

\author{
Much Djunaidi ${ }^{1}$, Nadari Octaviani Pahlevi ${ }^{1}$ \\ ${ }^{1}$ Jurusan Teknik Industri \\ Universitas Muhammadiyah Surakarta, Jalan Ahmad Yani, Pabelan, Kartasura, Surakarta 57162 \\ email : much.djunaidi@ums.ac.id \\ doi: https://doi.org/10.31315/opsi.v14i1.4476
}

Received: $10^{\text {th }}$ February 2021; Revised: $28^{\text {th }}$ May 2021; Accepted: $11^{\text {th }}$ June 2021;

Available online: $24^{\text {th }}$ June 2021; Published regularly: June 2021

\begin{abstract}
One of the activities of the Karawang ADM Engine Plant in component export is to mix part packing, which is the process of combining several component parts with a certain quantity box into one pallet. This is done to streamline delivery to the destination country. This research was conducted to analyze problems and make improvements in order to achieve the target of zero flow out with the poka yoke approach, to design processes or tools so that errors do not occur or at least can be detected or corrected. The flow out occurs when the clip hose part separates from the module and the part way brake actuator is left in the consumable area. Identify the problem using why analysis and the main factors that cause the flow out of man, methods, and environment factors. Some improvement ideas based on poka yoke ideas are presented at the end.
\end{abstract}

Keywords: mixed packing, multiple parts, flow out, poka yoke

\begin{abstract}
ABSTRAK
Salah satu aktivitas ADM Engine Plant Karawang dalam ekspor komponen adalah melakukan mix packing part, yaitu proses menggabungkan beberapa komponen part dengan quantity box tertentu menjadi satu pallet. Hal ini dilakukan untuk mengefisienkan pengiriman ke negara tujuan. Penelitian ini dilakukan untuk menganalisa masalah dan melakukan perbaikan guna mencapai target zero flow out dengan pendekatan poka yoke, untuk mendesain proses atau alat bantu agar kesalahan tidak terjadi atau minimal dapat dideteksi atau dikoreksi. Flow out yang terjadi adalah part clip hose terpisah dengan modulnya dan part way brake actuator tertinggal di area consumable. Identifikasi masalah menggunakan why analysis dan faktor utama yang menyebabkan flow out faktor dari man, methods, dan environment. Beberapa ide perbaikan berdasarkan gagasan poka yoke disampaikan pada bagian akhir.
\end{abstract}

Kata Kunci: mixed packing, multiple parts, flow out, poka yoke

\section{PENDAHULUAN}

ADM Engine Plant Karawang (selanjutnya disebut ADM) merupakan pabrik manufaktur yang memproduksi beberapa jenis part mesin untuk produk otomotif dan juga melakukan ekspor component. Ustriaji (2016) mengatakan ekspor secara umum adalah kegiatan yang menyangkut produksi barang/jasa yang diproduksi suatu negara untuk dikonsumsi di luar batas negara tersebut. Aktivitas pada bagian ekspor component adalah menerima pesanan komponen part dari negara tujuan, kemudian melakukan pengadaan barang dari supplier (Diedrich \& Jansen, 2007). Sebelum part dikirimkan ke negara tujuan, bagian ekspor component melakukan mix packing part, yaitu proses menggabungkan beberapa komponen part dengan quantity box tertentu menjadi satu 
pallet guna mengefisienkan dalam proses pengiriman ke negara tujuan ekspor.

Dalam proses mix packing part terdapat banyak kemungkinan terjadinya flow out. Flow out adalah proses aliran barang keluar yang tidak sesuai dengan pesanan, baik secara jenis ataupun secara quantity. Hal tersebut berdampak bagi performa kualitas pelayanan ADM dalam kegiatan ekspor component. Apabila performa menurun, tidak menutup kemungkinan akan kehilangan bisnis dan diambil alih oleh perusahaan lain.

Salah satu cara untuk melakukan suatu pekerjaan yang lebih baik adalah menggunakan alat bantu berdasarkan pendekatan poka yoke. Thareja (2016) mengatakan poka yoke (pemeriksaan kesalahan) adalah kata yang dibuat oleh insinyur manufaktur Jepang Shingeo Shingo, insinyur industri di perusahaan motor Toyota, yang mengklasifikasikan dan menulis karya definitif pada teknik ini pada tahun 1961. Menurut Hartini dan Bagus (2010), gagasan dasar poka yoke adalah untuk mendesain proses atau alat bantu agar kesalahan tidak mungkin terjadi atau minimal dapat dideteksi atau dikoreksi. Poka yoke merupakan strategi dan kebijaksanaan untuk mencegah defect di dalam sumbernya dengan cara melakukan inspeksi secara terus menerus demi mencapai zero defect product (Putri dan Wiwik 2019).

Beberapa rumusan masalah yang dibahas sebagai berikut: menjelaskan kondisi proses mix packing part saat ini, mengidentifikasi faktor penyebab masalah dari flow out ekspor komponen part, dan mengusulkan perbaikan berdasarkan identifikasi penyebab masalah. Manfaatnya adalah pengendalian dan pencegahan flow out pada export komponen sehingga dapat tercipta zero flow out sesuai dengan KPI (key performance indicator) dari ADM.

Tujuan dari penelitian yang dilakukan antara lain: mengidentifikasi flow out yang terjadi pada proses mix packing part, mengetahui faktor penyebab masalah dari flow out ekspor komponen part, dan memberikan rekomendasi perbaikan dengan poka yoke guna pengendalian dan pencegahan flow out ekspor komponen part.

\section{METODE}

Metode pengolahan data pada penelitian ini menggunakan metode analisis deskriptif kualitatif. Penelitian deskriptif yaitu mengumpulkan data berdasarkan faktor-faktor yang menjadi pendukung terhadap objek penelitian, kemudian menganalisa faktor-faktor tersebut untuk dicari peranannya. Kualitatif merupakan penelitian yang berhubungan dengan ide, persepsi, pendapat, kepercayaan orang yang akan diteliti dan kesemuanya tidak dapat diukur dengan angka (Prabowo dan Heriyanto, 2012).

Penelitian dan pengambilan data dilakukan pada tanggal 5 Agustus - 30 Agustus 2019 di PT. Astra Daihatsu Motor, Engine Plant, Karawang pada Departemen Export Component, Divisi Plant Administration KEP.

Metode pengumpulan data dilakukan dengan genba/observasi secara langsung dan wawancara. Wawancara dilakukan langsung kepada PIC receiving part, PIC mix packing part, foreman, dan operator yang bertugas pada area tersebut (data primer). Data sekunder yang diperoleh dari PT. Astra Daihatsu Motor yaitu data terjadinya flow out export component pada proses mix packing part. Peneliti juga melalukan studi pustaka terkait informasi pemecahan masalah guna menunjang penelitian yang dilakukan.

Analisis data yang telah diolah menggunakan pendekatan poka yoke. Menurut Nazlina (2005), inti dari poka yoke adalah merancang proses atau alat bantu sehingga kesalahan tidak mungkin terjadi atau setidaknya kesalahan tersebut mudah untuk dideteksi dan diperbaiki. Pelaksanaan konsep poka yoke dilakukan dalam tiga langkah :

1. Identifikasi kemungkinan salah yang masih dapat muncul dalam tindakan pencegahan

2. Tentukan cara untuk mendeteksi sebuah kesalahan atau kegagalan yang ada atau akan muncul

3. Identifikasi dan tentukan tindakan yang dilakukan pada saat kesalahan terjadi

Hudori dan Josafat (2017) mengatakan, poka yoke ini didasarkan pada filosofi bahwa orang tidak secara sengaja membuat kesalahan atau melakukan pekerjaan dengan tidak benar, tetapi kesalahan terjadi karena berbagai alasan. Poka yoke paling efektif ketika dikombinasikan dengan inspeksi sumber karena mencegah kesalahan dari menyebabkan cacat (Zhang, 2014). Langkah-langkah penelitian dapat dilihat pada flowchart Gambar 1. 


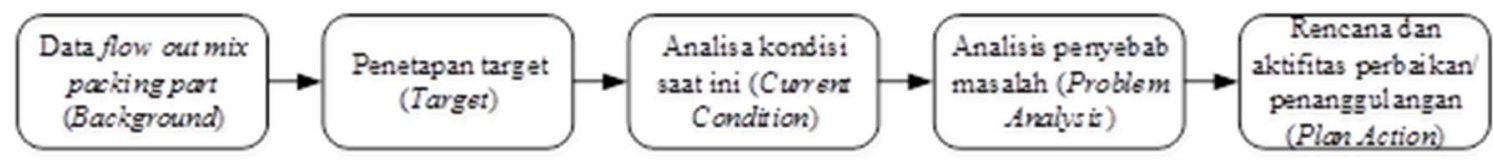

Gambar 1. Langkah-langkah penelitian
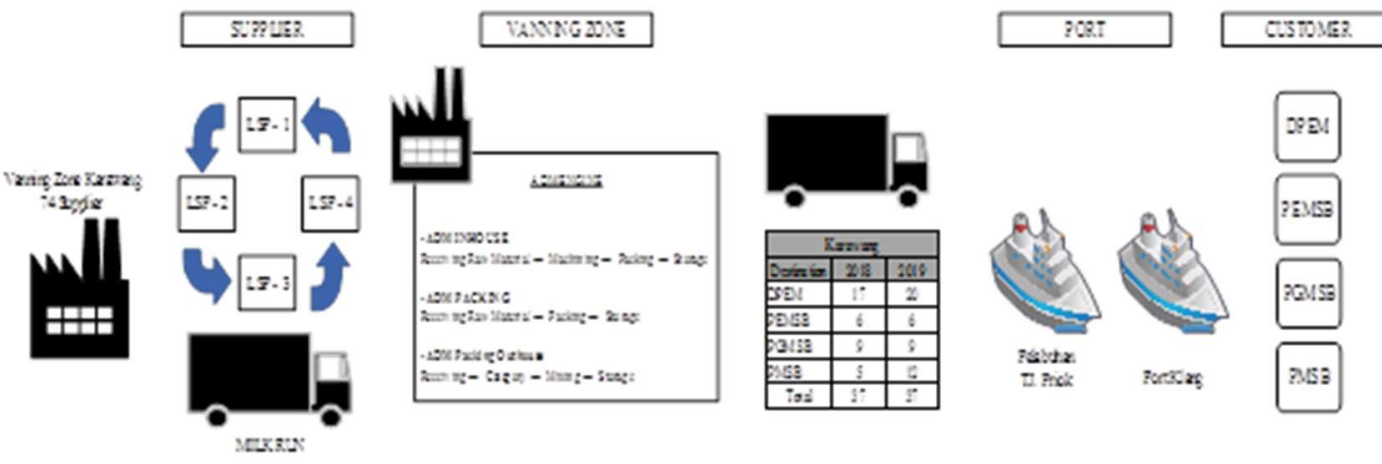

Gambar 2. Global Flow Export Component (Sumber: ADM)

\section{HASIL DAN PEMBAHASAN}

Gambar 2 menunjukkan global flow dari export component. Kegiatan yang dilakukan pada export component yang pertama adalah PT.ADM melakukan pengadaan komponen part ke 74 supplier dengan sistem Milk run. Singh dan Archana (2017) mengatakan, Milk run adalah metode pengumpulan barang dan produk di mana pengguna mengirim satu truk pada periode waktu tertentu untuk mengunjungi berbagai pemasok mengikuti rute yang telah ditentukan untuk mengumpulkan produk dan suku cadang, dan mengirimkannya ke tujuan. Proses yang dilakukan di PT. Astra Daihatsu Motor, Engine Plant adalah packing part dan mix packing part dalam satu pallet module.

Setelah dilakukan proses packing, PT. ADM melakukan vanning atau stuffing. Menurut Munir dkk. (2012), Stuffing adalah kegiatan yang dilakukan untuk memindahkan suatu barang dalam container (peti kemas) atau memasukan barang dari luar container ke dalam container. Peti kemas tersebut dikirim ke pelabuhan Tanjung Priok untuk dieskpor ke negara tujuan. Customer yang menjadi importer komponen part antara lain DPEM, PEMSB, PGMSB, PMSB.

\subsection{Data Flow Out Mix Packing Part}

Hal yang melatarbelakangi penelitian ini adalah ditemukan terjadinya flow out ekspor komponen part pada proses mix packing part yang terjadi selama bulan Januari - Agustus 2019. Data kejadian flow out dapat dilihat pada Tabel 1.

Berdasarkan Tabel 1 pada estimation time of departure (ETD) 20 Juli 2019 dengan nomer module I1E-MIX-00387 terdapat komponen part yang terpisah dari case module nya yaitu part CLIP, HOSE, seharusnya part tersebut satu module yang sama dan pengiriman container yang sama tetapi aktualnya dikirimkan pada batch pengiriman selanjutnya dengan container yang berbeda yaitu container no BSIU 9487319 dan BMOU 4473549. Untuk ETD 5 Agustus 2019 dengan nomer modul I1E-MIX-00574 terdapat komponen non pallet (direct supplier) yang tertinggal di area consumable (area receiving) yaitu part Way Brake Actuator. Terdapat beberapa supplier yang mengirimkan part tanpa pallet karena quantity box nya hanya sedikit. 
Tabel 1. Tabel Kejadian Flow Out Pada Proses Mix Packing Part

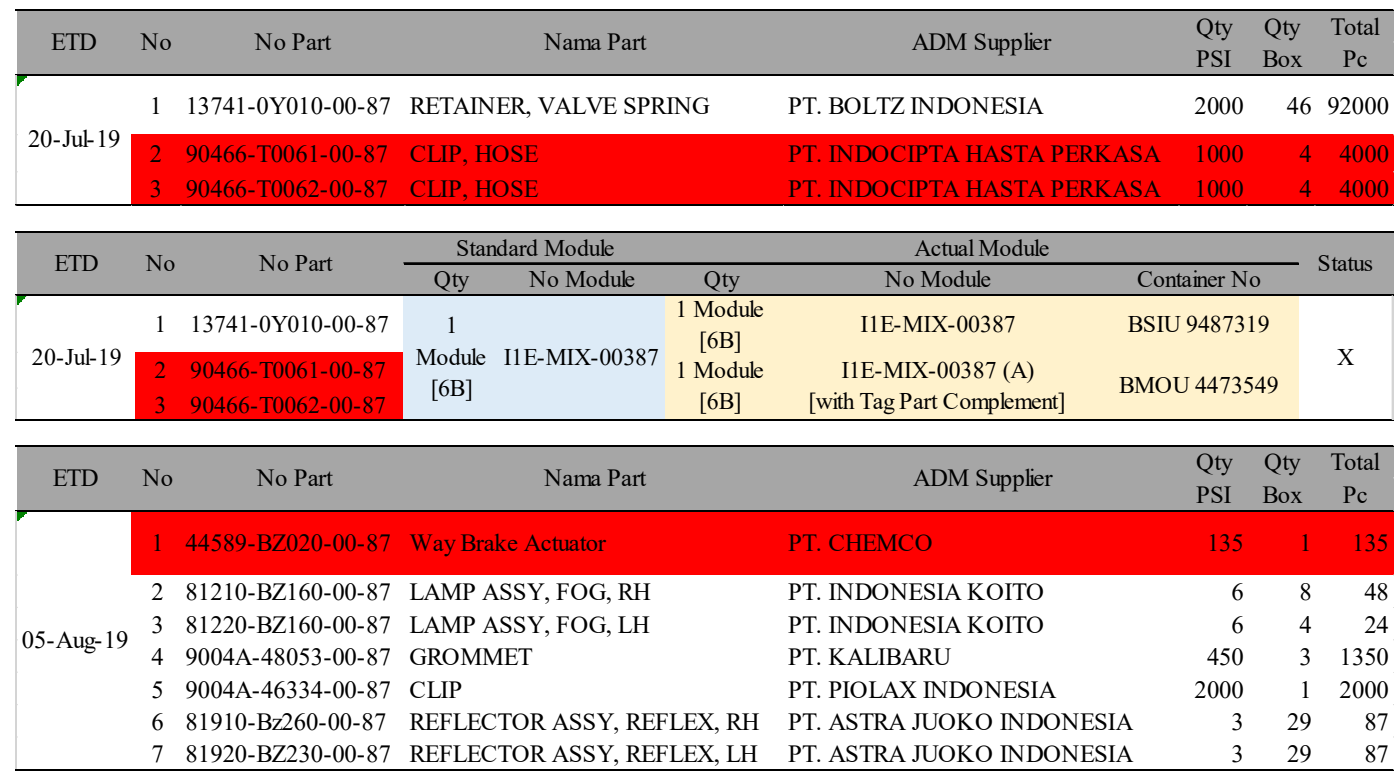

\begin{tabular}{|c|c|c|c|c|c|c|c|c|}
\hline \multirow{2}{*}{ ETD } & \multirow{2}{*}{ No } & \multirow{2}{*}{ No Part } & \multicolumn{2}{|c|}{ Standard Module } & \multicolumn{3}{|c|}{ Actual Module } & \multirow{2}{*}{ Status } \\
\hline & & & Qty & No Module & Qty & No Module & Container No & \\
\hline \multirow{7}{*}{ 05-Aug-19 } & 1 & 44589-BZ020-00-87 & \multirow{7}{*}{$\begin{array}{c}1 \\
\text { Module } \\
{[6 \mathrm{~B}]}\end{array}$} & \multirow{7}{*}{ I1A-MIX-00574 } & $\begin{array}{l}1 \text { Module } \\
{[6 \mathrm{~B}]}\end{array}$ & IA-MIX-00574 & SEGU-6065543 & \multirow{7}{*}{$\mathrm{X}$} \\
\hline & 2 & $81210-B Z 160-00-87$ & & & & \multirow{6}{*}{ IA-MIX-00574 } & \multirow{6}{*}{ BEAU-4566591 } & \\
\hline & 3 & $81220-B Z 160-00-87$ & & & & & & \\
\hline & 4 & $9004 \mathrm{~A}-48053-00-87$ & & & 1 Module & & & \\
\hline & 5 & 9004A-46334-00-87 & & & & & & \\
\hline & 6 & 81910-Bz260-00-87 & & & & & & \\
\hline & 7 & $81920-B Z 230-00-87$ & & & & & & \\
\hline
\end{tabular}

(Sumber: Separate Module Mix ADM, 2019)

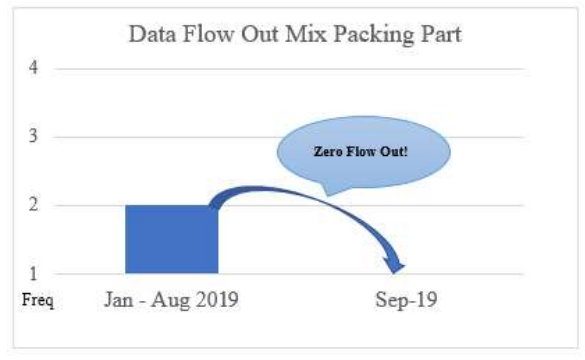

Gambar 3. Penetapan Target Zero Flow Out

\subsection{Penetapan Target}

Penetapan target improvement terdahap masalah yang terjadi dan ingin dihilangkan/ ditanggulangi. Gambar 3 menunjukkan bahwa flow out mix packing proses terjadi dengan frekuensi 2 kali pada periode Januari - Agustus 2019. Flow out tersebut harus dihilangkan agar mencapai kondisi yang ideal yaitu zero flow out. Alasan dari penetapan target diatas adalah berdasarkan KPI (key performance indicator) ADM.

\subsection{Analisa Kondisi Saat Ini}

Gambar 4 memperlihatkan flow proses pada export component part, mulai dari release order, receiving, mix packing, hingga vanning/ stuffing. Dari proses diatas diidentifikasi dimana masalah berpotensi terjadi. Potensi flow out terjadi yaitu pada part dikirimkan tanpa pallet dan diletakkan bercampur dengan area consumable tanpa identitas pallet, potensi flow out juga dapat disebabkan dari handling atau proses transfer part mixing dari area receiving ke area mixing, juga potensi masalah pada saat proses mix packing part itu sendiri.

\subsection{Analisis Penyebab Masalah}

Setelah melakukan observasi dan brainstorming bersama dengan foreman, supervisor, dan karyawan lapangan, didapatkan beberapa faktor yang menyebabkan atau bisa menjadi potensi terjadinya flow out pada proses mix packing part. Tabel 2 merupakan tabel why analysis untuk mencari akar penyebab permasalahan flow out mix packing part. 
Tabel 2. Analisis Penyebab Masalah Dengan Why Analysis

\begin{tabular}{|c|c|c|c|c|c|}
\hline Masalah & Faktor & Why 1 & Why 2 & Why 3 & Countermeasure \\
\hline \multirow{8}{*}{$\begin{array}{l}\text { Flow out } \\
\text { di mix } \\
\text { packing } \\
\text { part } \\
\text { process }\end{array}$} & Man & $\begin{array}{l}\text { Mis packing } \\
\text { mixing part }\end{array}$ & $\begin{array}{l}\text { PIC tidak } \\
\text { memahami proses } \\
\text { mixing part }\end{array}$ & $\begin{array}{l}\text { Changing point } \\
\text { PIC (PIC } \\
\text { pengganti ) }\end{array}$ & $\begin{array}{l}\text { Matriks skill PIC } \\
\text { untuk proses } \\
\text { mixing part }\end{array}$ \\
\hline & \multirow{6}{*}{ Methode } & \multirow{4}{*}{$\begin{array}{l}\text { Part } \\
\text { tertinggal di } \\
\text { area } \\
\text { receiving }\end{array}$} & \multirow{2}{*}{$\begin{array}{l}\text { PIC tidak tahu } \\
\text { jadwal transfer } \\
\text { part tanpa pallet } \\
\text { ke area mixing }\end{array}$} & \multirow{2}{*}{$\begin{array}{l}\text { Tidak ada jadwal } \\
\text { tetap transfer part } \\
\text { tanpa pallet ke } \\
\text { area mixing }\end{array}$} & $\begin{array}{l}\text { Membuat jadwal } \\
\text { tetap instruksi } \\
\text { transfer part tanpa } \\
\text { pallet ke area } \\
\text { mixing }\end{array}$ \\
\hline & & & & & $\begin{array}{l}\text { Membuat tagging } \\
\text { di pallet untuk } \\
\text { instruksi transfer } \\
\text { berdasarkan } \\
\text { kedatangan part }\end{array}$ \\
\hline & & & $\begin{array}{l}\text { Tidak ada } \\
\text { monitoring status } \\
\text { transfer part dari } \\
\text { area receiving ke } \\
\text { area mixing }\end{array}$ & $\begin{array}{l}\text { Tidak ada } \\
\text { checksheet khusus } \\
\text { transfer mixing }\end{array}$ & $\begin{array}{l}\text { Membuat } \\
\text { checksheet khusus } \\
\text { transfer part } \\
\text { mixing untuk PIC } \\
\text { Feeder }\end{array}$ \\
\hline & & & $\begin{array}{l}\text { Point pengecekan } \\
\text { receiving part } \\
\text { mixing hanya } \\
\text { based on casemark }\end{array}$ & $\begin{array}{l}\text { Tidak ada } \\
\text { checksheet khusus } \\
\text { enter part mixing }\end{array}$ & $\begin{array}{l}\text { Membuat } \\
\text { checksheet enter } \\
\text { part dengan point } \\
\text { check Qty Box }\end{array}$ \\
\hline & & $\begin{array}{l}\text { Containt } \\
\text { part } \\
\text { dimodul }\end{array}$ & $\begin{array}{l}\text { Tidak ada double } \\
\text { checking } \\
\text { checksheet, } \\
\text { checking hanya } \\
\text { oleh PIC }\end{array}$ & $\begin{array}{l}\text { Tidak ada validasi } \\
\text { checking ke } \\
\text { atasan }\end{array}$ & $\begin{array}{l}\text { Revisi S.O.P dan } \\
\text { menambahkan } \\
\text { point check } \\
\text { Atasan pada } \\
\text { checksheet }\end{array}$ \\
\hline & & $\begin{array}{l}\text { tidak sesuai } \\
\text { dengan } \\
\text { aktual }\end{array}$ & $\begin{array}{l}\text { Modul containt } \\
\text { part belum } \\
\text { complete sudah } \\
\text { dikirim ke vanning } \\
\text { storage }\end{array}$ & $\begin{array}{l}\text { Tidak tag } \\
\text { identitas module } \\
\text { finish mixing atau } \\
\text { open mixing }\end{array}$ & $\begin{array}{l}\text { Membuat identitas } \\
\text { pada mixing part ( } \\
\text { finish mixing dan } \\
\text { open mixing ) }\end{array}$ \\
\hline & Environment & $\begin{array}{l}\text { Part tanpa } \\
\text { pallet } \\
\text { tertinggal di } \\
\text { area } \\
\text { receiving }\end{array}$ & $\begin{array}{l}\text { Part tanpa pallet } \\
\text { diletakkan di area } \\
\text { consumable }\end{array}$ & $\begin{array}{l}\text { Tidak ada tempat } \\
\text { khusus untuk part } \\
\text { tanpa pallet di } \\
\text { area receiving }\end{array}$ & $\begin{array}{l}\text { Membuat space } \\
\text { khusus part tanpa } \\
\text { pallet di area } \\
\text { receiving dan di } \\
\text { area mixing }\end{array}$ \\
\hline
\end{tabular}

Penjabaran dari faktor masalah dengan why analysis dapat dilihat pada Tabel 2.

\subsection{Rencana Perbaikan atau Penanggulangan Masalah (Plan Action)}

Menurut Hartini dan Bagus (2010), gagasan dasar poka yoke untuk mendesain proses atau alat bantu agar kesalahan tidak mungkin terjadi atau minimal dapat dideteksi atau dikoreksi. Dengan gagasan tersebut rencana dan aktifitas perbaikan atau penanggulangan masalah flow out pada proses mix packing part dengan membuat rencana perbaikan (poka yoke) seperti pada Tabel 3.

Dari hasil analisis akar penyebab masalah flow out, maka dilakukan perbaikan seperti pada Tabel 3, untuk mencapai target zero flow out yang sudah ditentukan sebelumnya. Berikut ini merupakan rencana perbaikan/ penanggulangan masalah:

a. Matriks skill PIC kompetisi untuk proses mix packing part. Pembuatan matriks skill kompetisi yang didalamnya terdapat tingkat skill seorang PIC dalam menjalankan job, dengan tujuan sebagai pedoman untuk menentukan PIC atau penanggung jawab pada proses mix packing part. PIC yang memiliki skill cukup yang boleh menghandle proses mix packing part.

b. Membuat jadwal tetap instruksi transfer part mixing tanpa pallet ke area mixing. Jadwal instruksi transfer dijadikan pedoman pada saat handling part dari area receiving ke area mixing, untuk meminimalisir terjadinya part 


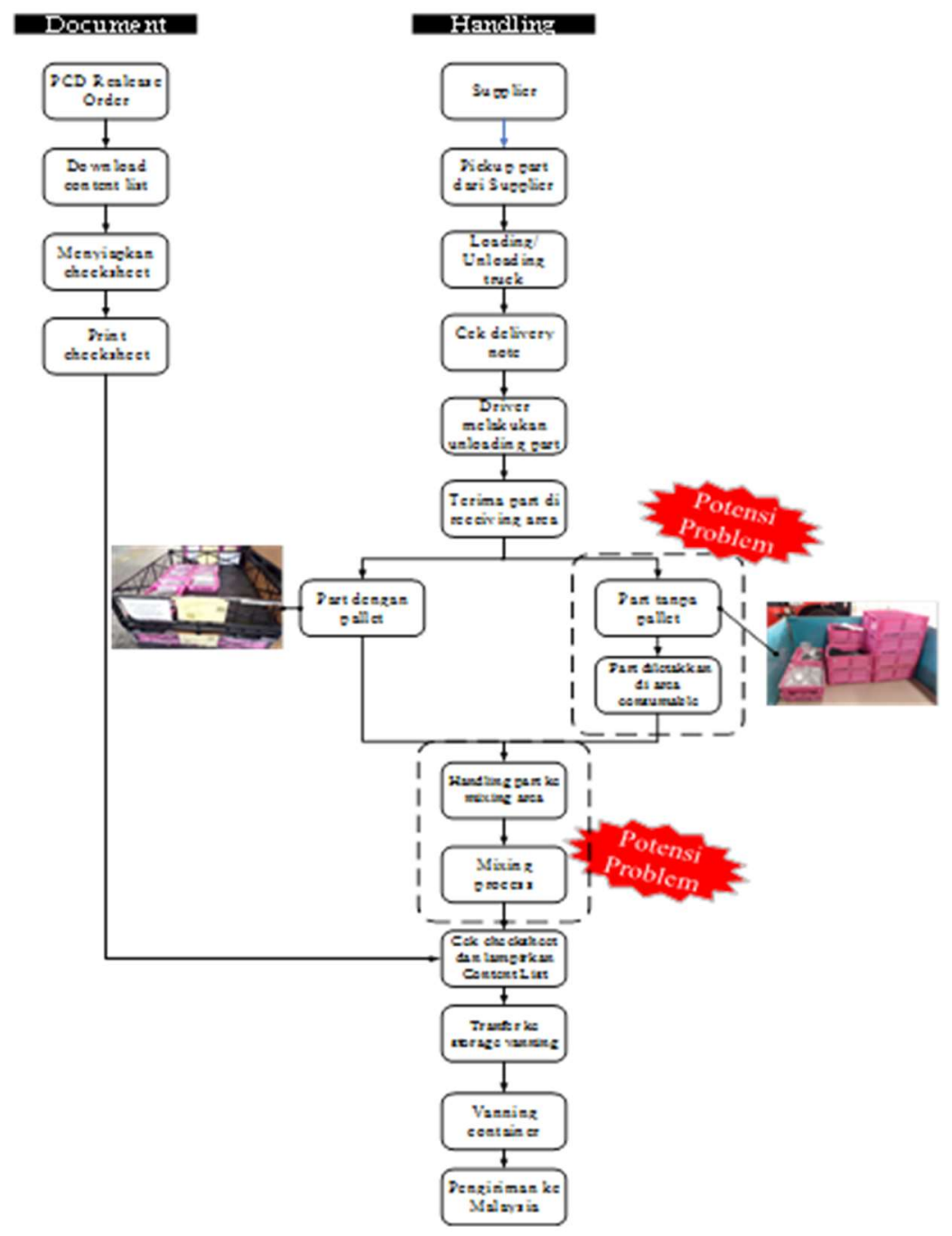

Gambar 4. Flow Process Export Component

yang belum di transfer (Zhang et al., 2014). Jadwal berdasarkan dari periode shipping yang dilakukan dua kali dalam 1 minggu.

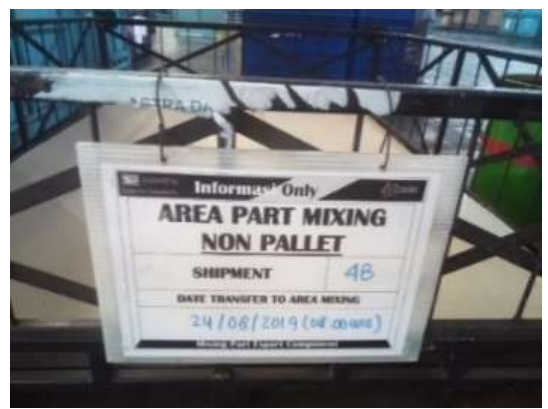

Gambar 5. Tagging Area Part Mixing Non-Pallet di Area Receiving

c. Membuat tagging untuk instruksi transfer part mixing tanpa pallet berdasarkan kedatangan. Satu module khusus tempat part mixing yang dikirimkan supplier disediakan untuk pallet (direct) di area receiving. Petugas memberi tagging yang didalamnya terdapat week shipment, tanggal dan jam transfer part mixing dari area receiving ke area mixing pada module. Tagging instruksi transfer dapat dilihat pada Gambar 5.

d. Membuat checksheet khusus transfer part mixing untuk PIC Feeder. Feeder adalah orang yang bertugas untuk mentransfer barang dengan forklift. Checksheet tersebut diisi oleh feeder ketika feeder sudah melakukan kegiatan transfer mixing part. Guna checksheet tersebut adalah untuk memonitoring apakah part mixing sudah di transfer ke area receiving atau belum (Lees, 1981).

e. Membuat checksheet khusus enter part mixing. Ketika part mixing sudah diterima di area receiving, PIC mixing melakukan 
Tabel 3. Rencana Perbaikan Dengan Poka Yoke

\begin{tabular}{|c|c|c|c|c|}
\hline No & Ide Perbaikan & Sebelum & Sesudah & Status \\
\hline 1. & $\begin{array}{l}\text { Matriks skill PIC kompetisi untuk } \\
\text { proses mixing part }\end{array}$ & $\begin{array}{l}\text { Tidak ada matriks skill } \\
\text { PIC mixing part }\end{array}$ & $\begin{array}{l}\text { Membuat matriks skill } \text { PIC } \\
\text { mixing part dan dijadikan } \\
\text { pedoman untuk changing PIC }\end{array}$ & Open \\
\hline 2. & $\begin{array}{l}\text { Membuat jadwal tetap instruksi } \\
\text { transfer part mixing tanpa pallet ke } \\
\text { area mixing }\end{array}$ & $\begin{array}{l}\text { Tidak ada jadwal } \\
\text { instruksi transfer pallet }\end{array}$ & $\begin{array}{l}\text { Jadwal instruksi transfer pallet } \\
\text { dari area receiving ke area mixing }\end{array}$ & Close \\
\hline 3. & $\begin{array}{l}\text { Membuat tagging untuk instruksi } \\
\text { transfer part mixing tanpa pallet } \\
\text { berdasarkan kedatangan }\end{array}$ & $\begin{array}{l}\text { Tidak ada tagging di } \\
\text { case pallet khusus }\end{array}$ & $\begin{array}{l}\text { Tagging instruksi transfer pallet } \\
\text { (shipment, date transfer) }\end{array}$ & Close \\
\hline 4. & $\begin{array}{l}\text { Membuat checksheet khusus } \\
\text { transfer part mixing untuk PIC } \\
\text { Feeder }\end{array}$ & $\begin{array}{l}\text { Tidak ada checksheet } \\
\text { transfer part mixing }\end{array}$ & $\begin{array}{l}\text { Monitoring transfer part mixing } \\
\text { dengan checksheet }\end{array}$ & Close \\
\hline 5. & $\begin{array}{l}\text { Membuat checksheet enter part } \\
\text { mixing dengan point check Qty Box }\end{array}$ & $\begin{array}{l}\text { Tidak ada checksheet } \\
\text { receiving part mixing }\end{array}$ & $\begin{array}{l}\text { Monitoring receiving part mixing } \\
\text { dengan checksheet }\end{array}$ & Close \\
\hline 6. & $\begin{array}{l}\text { Revisi S.O.P dan menambahkan } \\
\text { point check Atasan pada checksheet }\end{array}$ & $\begin{array}{l}\text { Tidak ada double check } \\
\text { dan validasi checksheet } \\
\text { oleh atasan }\end{array}$ & $\begin{array}{l}\text { Double check dan validasi } \\
\text { checksheet oleh atasan }\end{array}$ & Open \\
\hline 7. & $\begin{array}{l}\text { Membuat identitas pada mixing } \\
\text { part ( finish mixing dan open } \\
\text { mixing ) }\end{array}$ & $\begin{array}{l}\text { Tidak ada identitas open } \\
\text { mixing atau close mixing } \\
\text { pada case pallet }\end{array}$ & $\begin{array}{l}\text { Tag identitas open mixing atau } \\
\text { close mixing pada case pallet }\end{array}$ & Open \\
\hline 8. & $\begin{array}{l}\text { Membuat space khusus part tanpa } \\
\text { pallet di area receiving dan di area } \\
\text { mixing }\end{array}$ & $\begin{array}{l}\text { Tidak ada space khusus } \\
\text { part mixing tanpa pallet }\end{array}$ & $\begin{array}{l}\text { Space khusus part tanpa pallet di } \\
\text { area receiving dan area mixing }\end{array}$ & Close \\
\hline
\end{tabular}

monitoring dengan menggunakan checksheet khusus enter part mixing.

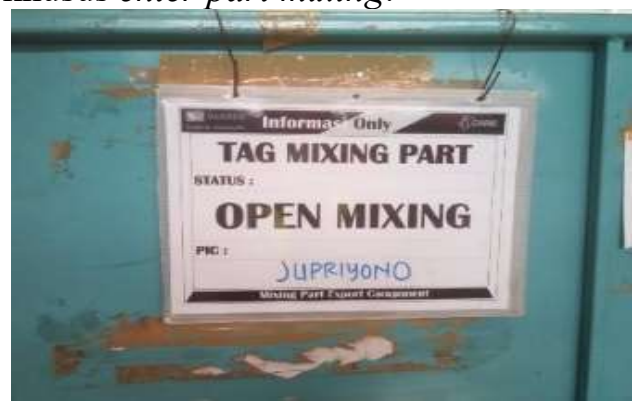

Gambar 6. Tag Mixing Part dengan status Open Mixing

f. Revisi prosedur operasional, double check dan menambahkan special activity cek dan validasi atasan pada checksheet. Revisi prosedur operasional, PIC melakukan konfirmasi kepada atasan, lalu atasan melakukan pengecekan no.module dan daftar part. Apabila sudah lengkap maka akan divalidasi oleh atasan, bila part belum lengkap maka PIC melakukan pelengkapan part. Setelah melakukan pelengkapan part, PIC cek kembali content part untuk memastikan lengkap dan sesuai, kemudian validasi terhadap atasan dan transfer ke area storage.

g. Membuat identitas pada mixing part (finish mixing dan open mixing). Untuk menghindari transfer module mixing yang belum lengkap content part nya ke area storage, maka diberikan tag identitas apakah module tersebut statusnya sudah close atau masih open mixing. Identitas open mixing, diberikan tagging open mixing dengan board yang digantungkan di pallet dapat dilepas pasang, sedangkan untuk tag close mixing, di pallet ditempelkan tag finish good mixing part. Tag mix packing part dapat dilihat pada Gambar 6 dan Gambar 7:

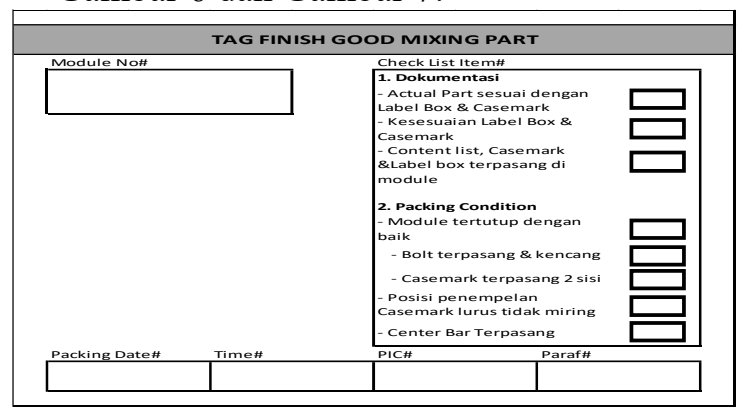

Gambar 7. Tag Mixing Close untuk Mixing Part 
h. Membuat space khusus part tanpa pallet di area receiving dan di area mixing. Untuk menghindari part tertinggal di area consumable, maka menyediakan space khusus 1 module part tanpa pallet di area receiving dan area mixing. Supplier yang mengirimkan part mixing tanpa pallet akan meletakkan part tersebut ke module tempat khusus di area receiving, module tersebut ditransfer ke area mixing dan module akan ditukar dengan module khusus part tanpa pallet yang berada di area mixing. Tag space khusus dapat dilihat pada Gambar 8.

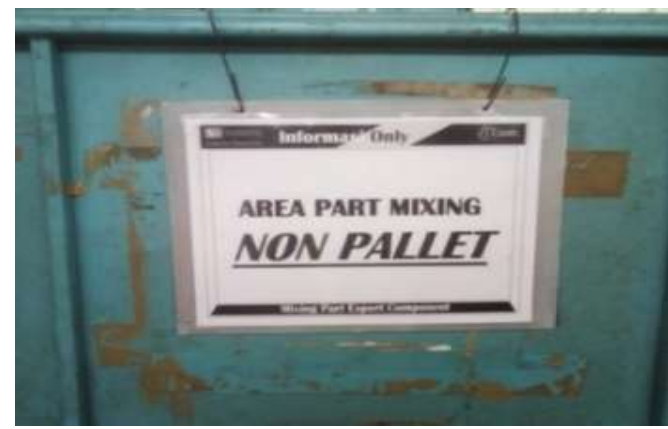

Gambar 8. Area Part Mixing Tanpa Pallet di Area Mixing

\section{KESIMPULAN}

Berdasarkan penelitian yang telah dilakukan maka dapat ditarik kesimpulan bahwa dalam proses mix packing part terdapat banyak kemungkinan terjadinya flow out. Kejadian flow out pada ETD 20 Juli 2019 yaitu part clip hose terpisah dengan modulnya dan ETD 5 Agustus 2019 part way brake actuator tertinggal di area consumable (area penerimaan).

Identifikasi masalah dengan menggunakan why analysis untuk mendapatkan akar permasalahan. Faktor utama yang menyebabkan flow out adalah faktor dari man, methods, dan environment.

Ide perbaikan berdasarkan gagasan dasar poka yoke adalah matriks ketrampilan PIC kompetisi untuk proses mix packing part, membuat jadwal tetap instruksi transfer part mixing tanpa pallet ke area mixing, membuat tagging untuk instruksi transfer part mixing tanpa pallet berdasarkan kedatangan, membuat checksheet khusus transfer part mixing untuk PIC feeder, membuat checksheet khusus enter part mixing, revisi S.O.P, double check dan menambahkan special activity check dan validasi Atasan pada checksheet, membuat identitas pada mixing part (finish mixing dan open mixing), membuat space khusus part tanpa pallet di area receiving dan di area mixing.

\section{DAFTAR PUSTAKA}

Diedrich, F., Jansen, K. (2007). "Faster and simpler approximation algorithms for mixed packing and covering problems." Theoretical Computer Science, 377 (1-3), 181-204. https://doi.org/10.1016/j.tcs.2007.02.064

Hartini, S., Bagus A.F. (2010). "Standardisasi Tata Letak Mesin dengan Metode Poka Yoke Untuk Mereduksi Breakdown Mesin dan Cacat Botol." Jurnal Standarisasi, 12 (1), 99-100.

Hudori, M., Josafat, M.S. (2017). "Poka Yoke untuk Pembuatan Palet Package Information di Bagian Shipping." Industrial Engineering Journal, 6 (1), 17.

Lees, S. (1981). "A mixed packing model for bone collagen." Calcified Tissue International, 33, 591-602. https://doi.org/10.1007/BF02409497

Munir, T.M., Adi P., Hardjono. (2012). "Optimalisasi Stuffing Dalam Terhadap Kelancaran Pemuatan Peti Kemas Ke Kapal Di Depo Peti Kemas Tanjung Tembaga PT. Meratus Line Surabaya." Jurnal Aplikasi Pelayaran dan Kepelabuhan. 3 (1), 12.

Nazlina (2005). "Studi Pengendalian Jumlah Cacat Dengan menggunakan Metode Poka Yoke di PT. Morawa Electric Transbuana." Jurnal Sistem Teknik Industri, 6 (4), 1-2.

Prabowo, A., Heriyanto (2013). "Analisis Pemanfaatan Buku Elektronik (e-Book) Oleh Pemustaka Di Perpustakaan Sma Negeri 1 Semarang." Jurnal Ilmu Perpustakaan, 2 (2), 5.

Putri, D.R., Wiwik, H. (2019). Zero Defect Pada Produksi Kantong Kraft Melalui Metode Poka Yoke Di Pt. Industri Kemasan Semen Gresik. Jurnal MEBIS (Manajemen dan Bisnis). 4(1): 48.

Singh, P., Archana, N. (2017). "Optimization of Supply Chain System by Implementing Milk Run Logistics Method - An Implementation Paper." International Journal of Innovative Research in Science, Engineering and Technology, 6 (4), 5490 
Thareja, P. (2016). "Poka Yoke: Poking into Mistakes for Total Quality!" Omni Science: A Multi-disciplinary Journal, 6 (2), 2.

Ustriaji, F. (2016). “Analisa Daya Saing Komoditi Ekspor Unggulan Indonesia di Pasar Internasional." Jurnal Ekonomi Pembangunan, 14(2), 150.

Young, N.E. (2001). "Sequential and parallel algorithms for mixed packing and covering," Proceedings 42nd IEEE Symposium on Foundations of Computer Science, Newport Beach, CA, USA, 2001, pp. 538-546. https://doi.org/10.1109/sfcs.2001.959930
Zhang, A. (2014). "Quality Improvement Through Poka-Yoke: From Engineering Design to Information System Design." International Journal of Six Sigma and Competitive Advantage, 8 (2), 14.

Zhang, M., Shen, J., Ma, S., Liu, D. (2014). "Study on Mixed Packing of Flotation Column." Proceedings of the 2014 International Conference on Mechatronics, Electronic, Industrial and Control Engineering (MEIC-14). November 2014. https://doi.org/10.2991/meic-14.2014.10 